\title{
Parenting Style in Early Marriage Mothers in Indonesia
}

\author{
Irwanto'), Ilham Ikhtiar'), Annis Catur Adi'), Andini Octaviana Putri3) \\ 1)Department of Pediatrics, Faculty of Medicine, Universitas Airlangga \\ 2) Department of Nutrition, Faculty of Public Health, Universitas Airlangga \\ 3)Department of Maternal and Child Health, Public Health Study Program, \\ Faculty of Medicine, Lambung Mangkurat University
}

\begin{abstract}
Background: Mothers who were married too young have a higher risk of to experience psychological and emotional problems influencing parenting style, which may have an impact on child development. However, prevalence of parenting style in early marriage mothers in Indonesia is still unknown. This study aimed to determine the prevalence of adopted parenting style on early marriage mothers.

Subjects and Method: A cross-sectional study was conducted in Martapura, Banjar Regency, South Kalimantan, Indonesia, from April 1 to May 30, 2018. Mothers who were married in early age (<21 years old) were enrolled using simple random sampling. The dependent variable was parenting style. The independent variables were education, family income, and number of children. Parenting style was measured by short version of parenting style and dimension questionnaire (PSDQ). The data were analyzed by Spearman test.

Result: Authoritative parenting style is the most common parenting style (54.6\%), followed by authoritarian (32.7\%), and permissive (12.7\%) parenting style. Education level $(\mathrm{r}=-0.07 ; \mathrm{p}=$ 0.325) decreased parental parenting style, but it was statistically non-significant. Family income $(\mathrm{r}=0.72 ; \mathrm{p}=0.302)$ and number of children $(\mathrm{r}=0.27 ; \mathrm{p}=0.700)$ increased parental parenting style, but it was statistically non-significant.

Conclusions: Education level decreases parental parenting style, but it is statistically nonsignificant. Family income and number of children increase parental parenting style, but it was statistically non-significant.
\end{abstract}

Keywords: parenting style, early marriage

\section{Correspondence:}

Irwanto. Department of Child Health, Faculty of Medicine, Universitas Airlangga. Jl. Prof. Dr. Moestopo 6-8, Surabaya, East Java, Indonesia. Email: Irwanto.idris@gmail.com. Mobile +62816500818.

\section{BACKGROUND}

According to the World Health Organization (WHO), 10 million women married before reaching 18 years every year (Bustreo et al., 2013). Marriage under 20 years of age in Indonesia is still relatively high (20\%) and ranked $37^{\text {th }}$ in the world and second rank highest in ASEAN (Loaiza and Wong, 2012). Based on the results of Indonesian National Basic Health Research
(RISKESDAS), $4.8 \%$ of Indonesian women were married at 10-14 years old and $41.9 \%$ married at the age of 15-19 years (Badan Penelitian dan Pengembangan Kesehatan Kementerian Kesehatan Republik Indonesia, 2013). Women who were married at an early age $(<21$ years) are in the emerging adulthood period. People who are at this time have left childhood and adolescent dependencies but do not yet have response- 
bilities that are owned by adults (Arnett, 2000). Emotional instability and lack of the responsibility of the mother who is at that age stage causes the mother have difficulty in developing care and attention to her child so that can impact to child nutrition and development (UNICEF, 2001). Early marriage in Indonesia was caused by several factors. Low education of parents and women's education causes the tendency for women to marry earlier. Besides that, early marriage has become a tradition in some ethnic groups, one of them is the Banjar ethnic. Mostly Muslim community, Indonesian culture is partially based on one of Islamic law interpretation which states that if adolescents are old enough, parents are encouraged to marry their child so that men and women will not do free sex (SmithHefner, 2005). In addition, early marriage is done because of the assumption in the community that girls must be immediately married so they do not become spinsters, other than the belief that rejecting a marriage proposal will result in women having difficulties to getting a partner. So that parents will marry their children as soon as possible even though they are not old enough (Dewi, 2018; Sniezek, 2013). Three parenting styles are exists according to Baumrind (Baumrind, 1991; DevPsy.org, 2018). Authoritative is a style of parenting with characteristics of parents that encourage children to be independent, but still provide limits and control over their actions. Authoritarian parenting is a parenting style with characteristics parents tend to limit and punish, parents tend to force existing rules without explaining them and easily show anger to children so that children are often unhappy, fearful, insecure when comparing themselves with others, not able to start activities, have weak communication skills, and have a high tendency to behave aggressively. Permissive parent- ing is a style of parenting characterized by high nurturance, but low in demands for maturity, control and communication, tends to free children without limits, does not control children, does not give punishment if children make mistakes, and do not have standards for child behavior, so the children tend to have low social skills, low self-control and non-independence. Some studies indicated that parenting style might affect growth and development of children (Kiuru et al., 2012; Vollmer and Mobley, 2013). A systematic review of 31 studies showed that uninvolved, indulgent or highly protective parenting was associated with higher child body mass index (BMI), whereas authoritative parenting was associated with a healthy BMI (Shloim et al., 2015). Another systematic review showed that authoritarian parents may thwart a child's exercise of self-control over eating due to established rules regarding eating and less reduction of BMI (Sokol et al., 2017). Not only physical health, studies also showed that self-esteem and quality of life in children raised by authoritative parenting is better compared to authoritarian and permissive parenting (Niaraki and Rahimi, 2013). However, there are still poor amount of data explaining parenting style for Indonesian population, especially in the early marriage mother family. Based on the background above, this study aims to assess the prevalence of adopted parenting style in early marriage mother population in Indonesia, as well as identifying its possible determinants.

\footnotetext{
SUBJECTS AND METHOD

1. Study design

This was a cross-sectional study conducted in East Martapura, Banjar Regency, South Kalimantan, Indonesia, from April 1 to May 30, 2018.
} 


\section{Population and sample}

The study population were mothers who were married in early age ( $<21$ years) with a child under five years old. Samples were collected using simple random sampling.

\section{Study variables}

The dependent variable was parenting style. The independent variables were education, family income, and number of children.

\section{Study instruments}

Data on socio-demographic characteristics of early marriage mothers (first age of marriage, first age of childbirth, mother's employment, family income, education, and number of children) were collected by using questionnaires. Education was measured based on the highest education attained by study subject. Family income was measured based on average paternal income. Cut-off was based on Ministry of Workforce 2017 Minimum Standard Wages Recommendation (MSWR) for South Kalimantan, which applied at the time of this study (IDR 2,258,000. Average income value under MSWR is considered low. Parenting style scale was based on Baumrind scales (DevPsy.org, 2018), with three subscales of styles, authoritarian, authoritative, and permissive parenting styles. Maternal parenting style was measured using short version of parenting style and dimension questionnaire (PSDQ) from Robinson et al. (Robinson, 2001). The short PDSQ then adjusted for Indonesian respondent based on a study concerning its consistency and reliability (Riany et al., 2018). The PSDQ assess parenting style based on score spectrum of answered question. Subjects were judged to have a particular parenting style if their scores matched to $75 \%$ or more on specific style, but have lower score on other style. Data then inputted into tables based on ordinal rank of parenting strictness, from permissive, authoritative, then authoritarian sub sequentially.

\section{Data analysis}

Collected data were manually checked for completeness and consistencies. Univariate analysis was used to describe the sociodemographic characteristics and parenting style. Bivariate analysis was conducted by Spearman test.

\section{Research ethics}

Ethical clearance was issued by Research Ethics Committee, Faculty of Public Health, Universitas Airlangga, Surabaya, in April 10, 2018, with clearance number 179-KEPK. All respondents were given information about the purpose and benefits of the study before completing the informed consent. There were no medical risks arising from the research and data confidentiality is guaranteed by anonymizing the questionnaire into label-based registry.

\section{RESULTS \\ 1. Sample characteristics by socio- demographic}

There are as many as 205 pairs of mothers and their children who were met our inclusion criteria. Most of mothers were married early are in the age 16-21 years (68\%). The highest first age of early marriage is 17 years old (29.8\%), with the youngest marriage age at 14 years old. Most of mothers (80.5\%) had their first child before 20 years old. The majority of mothers (65.9\%) had low level of education, as high as elementary and junior-high school. All samples (100\%) were unemployed and take a role as housewives. Most of them lived in family of more than 4 people, which also consisted their parents or parents-in-laws. Most of mothers (77.1\%) had one or two children, which is in line with Indonesian program of Family Planning. Most of the mothers who married too early $(72.7 \%)$ had a low family income $(<\mathrm{Rp} 2,258,000)$. The income was obtained from husband and most of the family heads worked as farmer, 
construction worker, entrepreneur, and other occupation. Most of their children were female aged under five years old (59.5\%). The majority of children under five years of age $(66.8 \%)$ were at the age of more than 24 months (2 years) with the youngest age in the range $0-6$ months (4.4\%) (Table 1).

Table 1. The characteristic of mother with Early Marriage

\begin{tabular}{|c|c|c|c|}
\hline Characteristic & Mean & $\mathbf{N}=\mathbf{2 0 5}$ & $\%$ \\
\hline \multicolumn{4}{|l|}{ Mothers } \\
\hline Age (years) & $21.04 \pm 1.58$ & & \\
\hline First Age of Marriage (years) & $17.01 \pm 1.49$ & & \\
\hline \multicolumn{4}{|l|}{ Highest Education Level } \\
\hline Elementary School & & 43 & 21.0 \\
\hline Middle School & & 92 & 44.9 \\
\hline High School & & 70 & 34.1 \\
\hline \multicolumn{4}{|l|}{ Family Income } \\
\hline Low & & 149 & 72.7 \\
\hline Medium to high & & 56 & $27 \cdot 3$ \\
\hline \multicolumn{4}{|l|}{ Employment Status } \\
\hline Unemployed & & 205 & 100.0 \\
\hline Employed & & $\mathrm{N} / \mathrm{A}$ & $\mathrm{N} / \mathrm{A}$ \\
\hline \multicolumn{4}{|l|}{ Number of Children } \\
\hline$\leq 2$ children & & 158 & 77.1 \\
\hline$>2$ children & & 47 & 22.9 \\
\hline \multicolumn{4}{|l|}{ Dominant Parenting Style } \\
\hline Permissive & & 26 & 12.7 \\
\hline Authoritative & & 112 & 54.6 \\
\hline Authoritarian & & 67 & 32.7 \\
\hline
\end{tabular}

\section{Frequency and Distribution of Parenting Style}

All subjects were responded the short PSDQ with tendency towards only one parenting style rather than combined Table 2. Statistical analysis on supposed determinants of parenting style in early marriage mothers

\begin{tabular}{lcc}
\hline Independent variables & $\mathbf{r}$ & $\mathbf{p}$ \\
\hline Education level & -0.07 & 0.325 \\
Family income & 0.72 & 0.302 \\
Number of children & 0.27 & 0.700 \\
\hline
\end{tabular}

parenting style. Most common parenting style of mothers who married early is authoritative parenting style (54.6\%). This is followed by authoritarian (32.7\%), and permissive (12.7\%) parenting styles. Table 2
0.700

\section{DISCUSSION}

In this study, we found a significant amount of authoritarian and permissive parenting style in early marriage mothers of East Martapura, South Kalimantan, Indonesia. Parenting style of early marriage mother has been a long unidentified in scientific communities, therefore, evidence supporting that early marriage mother tend to do non-ideal parenting style is lacking. However, there were already concern in which mothers who are married too early tend to not acknowledge responsibilities that are owned by adults (Melchiorre, 2013). Emotional instability and lack of sense of responsibility in mothers who are at this stage age are causing mother to experience difficulties caring their children, which finally 
may affect their children growth and development (Efevbera et al., 2017; Wodon et al, 2018; Sanjaya et al., 2018). This result in our suspects that in early marriage mothers, there exists less ideal parenting style at a significant amount. This further confirmed by our study result in which authoritarian and permissive parenting style distributivity is higher than expected, although authoritative parenting style is still dominating the population. Studies showed that authoritative parenting style is the ideal choice in the most cases. It is associated with better outcome on various aspects of child growth and development compared to authoritarian and permissive parenting style (Hirata and Kamakura, 2017; Kiuru et al., 2012; Niaraki and Rahimi, 2013; Shloin et al., 2015). Literatures revealed that good and ideal parenting to be applied to children is authoritative parenting style, because parents appear as a person who has a warm and loving nature towards children so that children often grow be a child who is cheerful, self-controlled, and self-sufficient (Kiuru et al., 2012; Vollmer and Mobley, 2013). It is important to note that parenting style also affects many aspects on child growth. Studies already demonstrated the effect of authoritative parenting style towards healthier average BMI in children aged 4-12 years old (Shloin et al., 2015). Authoritarian parenting style on the other hand, was linked to $35 \%$ higher obesity in children aged 2-5 years old compared to its authoritative counterpart (Kakinami et al., 2015). While permissive parenting might rise indulgent and uninvolved feeding styles, which associated with lower children's intakes of nutrient-rich foods, resulting in higher average BMI (Hoerr et al., 2009). However, it must be noted that result of a study involving 99 pairs of children and parents which reported that no moderating relationship was found between both parenting style and feeding style towards the practices of pressure to eat or monitoring and child weight (Hennessy et al., 2010).

Child development is another aspect which is highly affected by parenting style. A cross-sectional study involving 360 children and their parents in Roi Et Province, Thailand, which showed significant influence of parenting on development of children aged 3-6 years. The study showed that parents especially mothers who adopt authoritative parenting are 1.91 times more likely to have children with good development. In the mentioned study, parents with democratic parenting will form children who are able to control themselves and can cooperate with others (Nanthamongkolchai et al., 2007). The results of other study in Brong Ahafo region, Ghana, showed that there was relationship between parenting style with social development and children's independence (Mensah and Kuranchie, 2013). The study states that children who cared by authoritative parenting will be better in social skills than children who raised with authoritarian or permissive parenting.

We did not find any correlation between possible determinants such as education level, family income, and number of children, towards parenting style. Combination of family income and education has been thought to socially affect mother's decision-making ability (Parsons et al., 2015). However, it seemed that this is not the case of parenting style in early marriage mothers, where combined factors such as paternal dominance, mother psychological maturity, family and social interaction, as well as local cultural values supposed to play roles in creating parenting style. We also aware of the existence of belief in which mother who has higher number of children in family were expected to adopt 
stricter model of parenting. However, contrary to popular belief we did not find this to be true at least in early marriage mother population. Further study is needed to identify and confirm the determinants of parenting style.

There are limitations of this study. First, although this study achieved its goal to determine the prevalence of parenting style of a large population in Indonesia, it does not mean that this study result represents Indonesia as a whole. Difference in culture and socioeconomics between geographical area in Indonesia will affect the same study design if done in other part of Indonesia. Second, although we were able to show significant difference on parenting style distribution in early marriage mother group, we were unable to perform more reliable statistical tests due to the absence of control group. Third, while this study gives a picture of parenting style prevalence in early marriage mother, this study still cannot explain early marriage mothers parenting style implication towards child health. Hence, in this study we cannot draw conclusion in whether authoritarian and permissive actually yielded worse outcome compared to authoritative parenting style. Further studies are required to explore on how parenting style in early marriage mothers affects child growth and development.

Based on this study, it can conclude that in early marriage mothers, authoritative parenting style is the most commonly adopted parenting style, followed by stricter authoritarian style and less-strict permissive style. This study showed clearly that authoritarian and permissive style practice, which theoretically linked to worse outcome towards child growth and development, are exist at significant amount in early marriage mother population. We confirmed that determinants such as education level, family income, and number of children, has no correlation towards parenting style of early marriage mothers. Due to high amount of less-ideal parenting style, further studies are still required to determine the impact of this parenting style towards early marriage mother's child growth and development.

\section{ACKNOWLEDGEMENT}

The authors would also like to acknowledge to all respondent of this research for their cooperation and support. The authors also would like to say thank to all the people who help this research.

\section{CONFLICT OF INTEREST}

All authors declared no conflict of interest related to financial support or relationships during the proposal writings, data collection, analysis, and manuscript writings of this study.

\section{AUTHOR CONTRIBUTIONS}

Irwanto, Annis C. Adi, and Andini O. Putri designed, collected the samples, and conducted the initial analysis. Irwanto and Ilham Ikhtiar conducted further analysis and did the manuscript writing. All authors had read and approved this manuscript.

\section{REFERENCE}

Arnett JJ (2000). Emerging adulthood: A theory of development from the late teen through the twenties. Am Psychol, 55 (5): 469-80.

Badan Penelitian dan Pengembangan Kesehatan Kementerian Kesehatan Republik Indonesia (2013). Riset kesehatan dasar. Jakarta: Badan Penelitian dan Pengembangan Kesehatan Departemen Kesehatan Republik Indonesia. Available from: http://www.depkes.go.id/resources/download/general/- 
Hasil\%20Riskesdas\%202013.pdf

Baumrind D (1991). The influence of parenting style on Adolescent competence and subtance use. J Early Adolescence, 11(1): 56-95.

Bustreo F, Hunt P, Gruskin S, Eide A, Mcgoey L, Rao S, Songane F, et al (2013). Women's and Children's Health: Evidence of Impact of Human Rights. Geneva: WHO Press. Available from: https://apps.who.int/iris/bitstream/h andle/10665/84203/9789241505420 _eng.pdf;jsessionid=1FD2BACAFBFo 507121ABoB3F9oE91869?sequence $=$ 1.

DevPsy.org (2018). Diana Baumrind's (1966) Prototypical Descriptions of 3 Parenting Styles. Available from: http://www.devpsy.org/teaching/par ent/baumrind_parenting_styles.pdf

Dewi N (2018). Child marriage in short stories from Indonesia and Bangladesh: victor, survivor, and victim. IJHS, 2 (1): 51-60.

Efevbera Y, Bhabha J, Farmer PE, Fink G (2017). Girl child marriage as a risk factor for early childhood development and stunting. Soc Sci Med, 185: 91-101.

Hennessy E, Hughes SO, Goldberg JP, Hyatt RR, Economos CD (2010). Parent behavior and child weight status among a diverse group of underserved rural families. Appetite, 54 (2): 36977.

Hirata H, Kamakura T (2017). The effects of parenting styles on each personal growth initiative and self-esteem among Japanese University Students. Int J Adolesc Youth, 23 (3): 325-33.

Hoerr SL, Hughes SO, Fisher JO, Nicklas TA, Liu Y, Shewchuk RM (2009). Associations among parental feeding styles and children's food intake in families with limited incomes. Int $\mathrm{J}$
Behav Nutr Phys Act, 6: 55.

Kakinami L, Barnett TA, Séguin L, Paradis G (2015). Parenting style and obesity risk in children. Prev Med (Baltim), 75: 18-22.

Kiuru N, Aunola K, Torppa M, Lerkkanen MK, Poikkeus AM, Niemi P, Viljaranta J, et al. (2012). The role of parenting styles and teacher interactional styles in children's reading and spelling development. $J$ Sch Psychol, 50(6): 799-823.

Loaiza E, Wong S (2012). Marrying too Young: End Child Marriage. Jensen L, Marshall A, editors. New York: The United Nations Population Fund, p. 176. Available from: https://www.unfpa.org/sites/default/files/pub-pdf/MarryingTooYoung.pdf

Melchiorre A (2013). A minimum common denominator? Minimum ages for marriage reported under the convention on the rights of the child. child, early and forced marriage: Women's Human Rights and Gender Section. New York, USA: OHCHR. Available from: https://www.ohchr.org/EN/Issues/Women/WRGS/Pages/ChildMa rriage.aspx

Mensah MK, Kuranchie A (2013). Influence of parenting styles on the social development of children. Acad J Interdiscip Stud, 2 (3): 123-30.

Nanthamongkolchai S, Ngaosusit C, Munsawaengsub C (2007). Influence of parenting styles on development of children aged three to six years old. J Med Assoc Thai, 90 (5): 971-6.

Niaraki FR, Rahimi H (2013). The impact of authoriative, permissive, and authoritarian behavior of parents on selfconsept, psychological health and life quality. J Nat Soc Sci, 2 (1): 78-85.

Parsons J, Edmeades J, Kes A, Petroni S, Sexton M, Wodon Q (2015). Economic 
impacts of child marriage: A review of the literature. Rev Faith Int Aff, 13 (3): 12-22.

Riany YE, Cuskelly M, Meredith P (2018). Psychometric properties of parenting measures in Indonesia. Makara Hum Behav Stud Asia, 22 (2): 75.

Robinson CC, Mandleco B, Olsen SF, Hart $\mathrm{CH}$ (2001). Parenting style \& dimensions questionnaire- short version (PSDQ-short version) contructs scoring key. In: Touliatos J, Perlmutter BF, Holden GW, editors. Handbook of Family Measurement Techniques Vol 3. Thousand Oaks, CA: SAGE Publication Inc.

Sanjaya A, Narendra MB, Irwanto, Suryawan A, Irmawati M, Efendi F (2018). Early marriage and its relationship with child development. Indian $\mathrm{J}$ Public Heal Res Dev, 9 (9): 193-8.

Shloim N, Edelson LR, Martin N, Hetherington MM (2015). Parenting styles, feeding styles, feeding practices, and weight status in 4-12 year-old children: A Systematic Review of the Literature. Front Psychol, 6: 1849.

Smith-Hefner NJ (2005). The new muslim romance: Changing patterns of courtship and marriage among educated Javanese Youth. J Southeast Asian Stud, 36 (3): 441-59.

Sniezek T (2013). Negotiating marriage: A process model of heterosexual engagement. SAGE Open, 3 (3): 1-14.

Sokol RL, Qin B, Poti JM (2017). Parenting styles and body mass index: a systematic review of prospective studies among children. Obes Rev, 18(3): 281-92.

United Nations Children's Fund (UNICEF) (2001). Early marriage: Child spouses. Available from: https://www.unicef-irc.org/publications/pdf/digest7e.pdf

Vollmer RL, Mobley AR (2013). Parenting styles, feeding styles, and their influence on child obesogenic behaviors and body weight. A Review. Appetite, 71: 232-41.

Wilopo SA (2010). Kebijakan keluarga berencana dan kesehatan reproduksi menuju ke MDGs. In: Tukiran, Pitoyo JA, Kutanegara PM, editors. Keluarga Berencana dan Kesehatan Reproduksi. 1st ed. Yogyakarta: Pustaka Pelajar.

Wodon Q, Male C, Nayihouba A, Onagoruwa A, Savadogo A, Yedan A, Kes A, et al. (2018). Economic impacts of child marriage in Ethiopia: Synthesis report. Conference Edition. Washington, DC, USA: The World Bank and ICRW. Available from: https://openknowledge.worldbank.org/ 